Received: 1.5.2020; Revised: 9.9.2020; Accepted: 11.11.2020; Published online: 29.11.2020

\title{
DETERMINANTS OF TECHNICAL EFFICIENCY OF SMALL-HOLDERS YAM FARMERS IN NIGERIA
}

\author{
Mercy Ebere NDUBUEZE-OGARAKU *1 (iD), Olutola Ayodele ADEYOOLA ${ }^{1}$, Cecilia Akuchinyere \\ NWIGWE ${ }^{2}$ (iD)
}

\author{
Address: \\ ${ }^{1}$ Department of Agricultural Economics \& Extension, Faculty of Agriculture, University of Port Harcourt Choba. PMB \\ 5323, East-west Road, Choba, Rivers State, Nigeria \\ ${ }^{2}$ Department of Agricultural Economics \& Extension, Faculty of Agriculture, Nnamdi Azikiwe University, Awka, \\ Anambra State, Nigeria \\ * Corresponding author's email: mercy.onu@ uniport.edu.ng
}

\begin{abstract}
Research background: Yam is rated as a principal tuber crop in the Nigeria economy, contributing to more than 200 dietary calories per capita daily in West Africa. It's also an important source of income generation and trade. However, increase in yam production over the years is attributed more to the large area planted than to increase in farm level productivity.

Purpose of the article: This study aimed at estimating the determinants of technical efficiency and inefficiency levels in small-holder yam farms in Nigeria. The research specifically determined farm level technical efficiency and estimated farmers' socioeconomic variables that contributed to inefficiency level in yam production in Nigeria.

Methods: Cross sectional data was collected from 80 yam farmers, randomly selected from the study area. Descriptive statistics (frequency, mean and percentage) and Cobb Douglas stochastic frontier production function model were the analytical tools used.

Findings \& value added: Results indicated that the farmers were fairly educated and mainly males (75\%) with a mean age of 36 years. Farmers level of education and their age showed negative influence on technical efficiency, while household size and farming experience showed positive influence on technical efficiency. MLE estimates indicated that coefficients of farm size and yam seedlings were significant at 5\% while fertilizer and labour were not significant. Mean efficiency of yam farmers was $94.6 \%$, indicating an allowance of $5.4 \%$ for improvement. The finding suggests that there is need to support yam farmers in the use of modern techniques in yam production, which would encourage older and educated farmers to remain in farming. High incidence of pest and diseases and high cost of farm labour were among other major challenges faced by the farmers. It is recommended that programmes that would help improve farmers' access to input supplies at subsided rate should be put in place to enhance farm productivity.
\end{abstract}

Key words: determinants; technical efficiency; small-holders; yam farmers

JEL: C01; C21; D22; D24

\section{INTRODUCTION}

Yams (Dioscorea spp) are annual or perennial tuberbearing and climbing plants with over 600 species, out of which six are economically important in terms of food and medicine (International Institute for Tropical Agriculture IITA, 2007). It belongs to the genus "Dioscorea" and family "Dioscoreaceae", a tropical crop with many species, which originated from South East Asia and was brought into West Africa in the 16th century. It is one of the principal tuber crops in the Nigeria economy, in terms of land under cultivation and in the volume and value of production (Bamire and Amujoyegbe, 2005). Yam is rated as an important tuber because it contains a higher percentage of protein and vitamin C. Yam contributes more than 200 dietary calories per capita daily for more than 150 million people in West Africa and also an important source of income generation and trade (Babaleye, 2005; Reuben and Barau, 2012). It also has an important social status in gatherings and religious functions, which is assessed by the size of yam holdings one possesses. Yam is a preferred food and a food security crop in some sub-Saharan African countries (IITA, 2008). The nutritional composition of yam includes $70 \%$ water, $25 \%$ carbohydrate, $1 \%$ sugar and $3-4 \%$ protein (Onwueme, 2008). Yam also plays vital roles in traditional culture, rituals and religion; as well as local commerce of African people (Izekor and Olumese, 2010). Yam tubers may be eaten with sauce direct after roasting, boiling or frying in oil. The tubers may also be pounded into a thick paste after boiling and is eaten with soup. It may be processed into flour or cooked into pottage with added protein sauce and oils.

In Nigeria, yam production increased from $45,409.800$ tons in 2016 to $46,912.650$ tons in 2017 at end of the year with an average of 30,343.870 tons between 1995 and 2017. The highest production was 46,912.650 tons in 2017 and lowest was 22,522.500 tons in 2001 
(National Bureau of Statistics, 2017). Nevertheless, yam production in Nigeria has doubled more over the past 10 years, from 22.5 million tons in 2001 to 46.9 million tons in 2011 (NBS, 2012). The increase in output is attributed more to the large area planted to yam than to increased productivity (Zaknayiba and Tanko, 2013).

The study of efficiency in agriculture is based on certain economic theories which describe various ways production resources could be used to achieve maximum output level; one of which is technical efficiency, an engineering concept for measuring the performance of the system given the available resources. Technical efficiency is associated with behavioural objectives of maximization of output (Battese and Coelli, 1995). However, production cannot be carried out in isolation since a farm is considered as an economic unit with scarce resources. According to Ahmed et al. (2016), a producer is only efficient if he/she achieves objectives of production and inefficient if he/she fails to achieved its firms' objectives. Technical efficiency deals with efficiency in relation to factor-product transformation. For a farm to be called technically efficient, it has to produce at the production frontier level. However, this is not always the case due to random factors such as bad weather, animal destruction and or farm specific factors, contributing to producing below the expected output frontier (Battese and Coelli, 1995). They further argued that technical efficiency goes beyond evaluation based on average production to the one that is based on best performance among a given category. It is related to productivity where inputs are transformed into outputs.

Over the years, the farm hectare of yam production has been increasing with corresponding increases in the usage of inputs. Unfortunately, the increase in output seems not to have been commensurable with those in input usage (Reuben and Barau, 2012). However, the Nigerian Government made concerted efforts to encourage larger investment in the agricultural sector, including product such as yam for export. In 1998, the Nigerian Government initiated an Export Promotion Incentive Scheme. Under this scheme, some staple foods including yam were delisted from the export prohibition list. In 2001, the Nigerian Government initiated the Root and Tuber Expansion Program (RTEP) to improve farmers' productivity and profits from root and tuber crops. In 2003, an export subsidy of $10 \%$ on agricultural commodities was introduced and remained in place till date (Akande and Ogundele, 2009). Despite the government initiatives, Oladeebo and Okanlawon (2010) noted that the absolute level of yam production has remained static over a decade. This static trend may not be unconnected with production resources which are not being efficiently utilized. It is absolutely important to assess the level of technical efficiency among small holder farmers because of their contribution to the food security in Nigeria. It is on this note, the study was undertaken to determine technical efficiency of yam production in Ado Ekiti Local Government Area (L.G.A.), Ekiti State, Nigeria. Specifically, socio economic characteristics of yam farmers in the study area were identified and described; technical efficiency and inefficiency of yam farmers in Ado Ekiti L.G.A., Ekiti State were determined and major constraints in yam production were also identified.

\section{DATA AND METHODS}

\section{Area of Study}

The study was carried out in Ado Ekiti Local Government Area of Ekiti State Nigeria. Ado Local Government Area is a Local Government Area (LGA) which is among the 16 LGA's in Ekiti State. The population of the LGA according to National Population Commission (2006) was 313, 690 persons with projected figure of 427,700 people in 2016 . The land area is $293 \mathrm{~km}^{2}$ with a population density of $1,460 / \mathrm{km}^{2}$. The LGA is located in Ekiti State which is located between Latitude $7^{\circ} 37^{\prime \prime}$ and $15^{\circ} 99^{\prime \prime}$ and Longitude $5^{\circ} 13^{\prime \prime} 17^{\circ} 04^{\prime \prime} \mathrm{E}$. The State is bounded on the south and on the East by Ondo State, on the west by Osun State and on the northern side by Kwara and Kogi State. The climate of the state is tropical with two distinct seasons, the rainy season which last from April to October and dry season from November to March. The vegetation of Ekiti state is guinea savannah including all forms of fauna and flora with an annual rainfall of $1,400 \mathrm{~mm}$. The main occupations of the people are farming and trading. The major agricultural crops cultivated include yam, cassava, maize, cocoyam, tomato among others.

This study adopted stochastic frontier production function approach used by different scholars who carried out similar studies in the past. Among others Mango et al., (2015) adopted stochastic frontier model with linearized Cobb Douglas production function and determined technical efficiency in smallholder maize production in Zimbabwe. They found that maize output positively responded to increase in inorganic fertilisers, seed quantity, human labour and cultivated area. Azumah., Donkoh and Awuni, (2019) applied stochastic frontier analysis (SFA) in correcting bias in sample selection in a study in Northen Ghana, which determined technical efficiency (TE) and technology gap using cross-sectional data. The study showed that corrected sample selection TE estimates were marginally higher. However, it was reported that in the absence of appropriate correcting tools, inefficiency was overestimated while the gap in performance between irrigation farmers and their rain-fed counterparts was underestimated. Edeh and Awoke (2009) also employed a Cobb-Douglas stochastic frontier production function in the measure of technical efficiency level in improved cassava production. The study indicated that fertilizer application and tractor significantly increased cassava output at 5\% level. MuhammadLawal, Omotesho and Falola (2009) used stochastic frontier model in the analysis of the technical efficiency of the Youth-in-Agriculture Programme in Ondo State, Nigeria which found that efficiency differentials exist among the youths in the programme. Furthermore, Onyenweaku, Igwe and Mbanasor (2005) applied stochastic frontier production function model in the study of technical efficiency of yam production in Nasarawa State, Nigeria. Based on the evidence of applications of the model in several related studies in the past, stochastic frontier production function model is viewed as the most 
appropriate model in the study of technical efficiency of farms in Nigeria.

\section{Sampling Technique}

A two- stage random sampling technique was adopted in the selection of the respondents for the study. In the first stage, purposive sampling technique was employed in the selection of 4 villages out of the 12 villages in the Local Government Area. The four villages, namely, Erinfun, Emirin, Igirigiri, and Ilokun, were selected due to high concentration of yam farmers in the area. The second stage was the random selection of twenty (20) respondents from each of the selected villages giving, 80 respondents as the sample size.

\section{Method of Data Collection}

Data used for this study was essentially from primary data source which includes, the use of questionnaire showing various enquiries that was gotten from the yam farmers and from secondary data source which includes data already published in books and journals. The major instrument that was used in collecting the primary data was a well-structured questionnaire, which was administered to yam farmers through personal interviews, personal observations, and farm records.

Method of Data Analysis: Descriptive statistic such as mean, frequency distribution and percentage was used to analyse the socioeconomic features of the respondents; Stochastic frontier 4.1 version model developed by Battese and Coelli (1995) was used to analyse the technical efficiency and inefficiency of farmers while a 4point Likert Scale Ranking was used to rank and identify constraints which hindered the efficiency of yam production according to their order of importance.

\section{Model Specification}

The stochastic frontier model adopts the Cobb-Douglas model estimate (double log). This has both efficiency parameters and inefficiency parameters. The technical efficiency model is explicitly specified as Eq. 1.

$$
\begin{aligned}
& \ln Y=\beta_{0}+\beta_{1} \ln X_{1}+\beta_{2} \ln X_{2}+\beta_{3} \ln X_{3}+ \\
& \beta_{4} \ln X_{4}+\left(v_{i}-u_{i}\right)
\end{aligned}
$$

Where:

$Y$ Farm output in $\mathrm{kg}$ of the i-th farm;

$\beta_{0} \quad$ Constant;

$\beta_{1}-\beta_{4}$ Coefficients;

$X_{1}-X_{4}$ Estimated efficiency parameters;

$X_{1} \quad$ Land area cultivated;

$X_{2} \quad$ Labour in man-days;

$X_{3} \quad$ Quantity of seedlings used in $\mathrm{kg}$;

$X_{4}$ Quantity of fertilizer used in $\mathrm{kg}$;

$v_{i}-v_{i} \quad$ Composite error terms;

$v_{i}-v_{i}$ are assumed to be independently and identically distributed;

$v_{i} \quad$ is a random error, which is associated with random factors not under the control of the farmers;

$v_{i}$ is a non-negative random variable, associated with technical inefficiency in production.

Technical inefficiency model is expressed as Eq. 2.

$U_{i}=\delta_{0}+\delta_{1} Z_{1}+\delta_{2} Z_{2}+\delta_{3} Z_{3}+\delta_{4} Z_{4}$
Where:

$\mathrm{U}_{\mathrm{i}}$ Technical inefficiency;

$\delta_{1} \quad$ Age of the farmers (years);

$\delta_{2} \quad$ Household size in persons;

$\delta_{3} \quad$ Level of education in number of years spent schooling;

$\delta_{4} \quad$ Farming experience in years spent farming.

The four point Likert Scale Ranking includes:

4 Strongly agree

3 Agree

2 Disagree

1 Strongly disagree

\section{RESULTS AND DISCUSSION}

The results in Table 1 show the socioeconomic characteristics of yam farmers. It was observed that majority of the farmers $(48.8 \%)$ were between the age range of 31- 40 years and $75 \%$ of them were males. This clearly shows that yam farmers in the study area were in their productive age. The active age would likely mean that the farmers possessed physical strength which is required in doing farm operations. This result disagrees with the findings of Ajibefun and Abdulkadiri (1999); Ekunwe et al. (2008), which reported that older farmers are dominating in farm activities in Delta and Kogi States Nigeria.

The data further showed that majority $76.3 \%$ of the respondents were married. This may have enabled them to own reasonable family size which is a major source of farm labour supply in developing countries. This result supports the finding of Oluwatusin (2011), which reported that household size of farm families was 7 persons on average in Osun State, Nigeria. It was also noted that about $61.3 \%$ of the respondents had an average farming experience of 11 years. This clearly shows that yam farmers in the area were relatively experienced in farm business. The result on educational level shows that $21.3 \%$ and $40 \%$ of them had primary and secondary school education respectively. This is an indication that the farmers in the study area were fairly educated and literate. This characteristic may have enabled them made production management decisions that enhanced yam productivity in the area. However, this is contrary to the report of Okoruwa, Ogundele and Oyewusi (2006) on efficiency of rice farmers in North Central Nigeria which reported earlier that $75 \%$ of the farmers had primary education. The data observed that majority $55 \%$ of the farmers practiced mixed cropping while the remaining $45 \%$ practiced sole cropping. The result further showed that most of the respondents $(65 \%)$ acquired farm land through family inheritance and purchase while $35 \%$ of them acquired land through rent payment. It was also indicated that $52.5 \%$ of the farmers had farm land sizes that was less than one hectare with a mean of farm size of 0.84 hectares. This corroborates with the findings of Ndubueze-Ogaraku and Ogbonna (2016) which, observed that the largest farm size of rice farmers in Abia State was within the range 0.1-0.9 hectares. 
Table 1: Socioeconomic characteristics of the respondents

\begin{tabular}{|c|c|c|}
\hline Variables & Frequency & Percent \\
\hline \multicolumn{3}{|l|}{ Age in years } \\
\hline Below 20 & 25 & 2.5 \\
\hline $21-30$ & 9 & 11.3 \\
\hline $31-40$ & 39 & 48.8 \\
\hline $41-50$ & 23 & 28.8 \\
\hline 51 and above & 7 & 8.8 \\
\hline Mean age & 36 & \\
\hline \multicolumn{3}{|l|}{ Sex } \\
\hline Male & 60 & 75 \\
\hline Female & 20 & 25 \\
\hline \multicolumn{3}{|l|}{ Marital status } \\
\hline Single & 7 & 8.8 \\
\hline Married & 61 & 76.3 \\
\hline Separated & 5 & 6.3 \\
\hline Widowed & 7 & 8.8 \\
\hline \multicolumn{3}{|l|}{ Household size in persons } \\
\hline $1-5$ & 64 & 80 \\
\hline $6-10$ & 15 & 18.8 \\
\hline $11-15$ & 1 & 1.2 \\
\hline Mean household size in persons & 5 & \\
\hline \multicolumn{3}{|l|}{ Farm experience in years } \\
\hline$<10$ & 49 & 61.3 \\
\hline $11-20$ & 22 & 27.5 \\
\hline $21-30$ & 6 & 7.5 \\
\hline $31-40$ & 3 & 3.8 \\
\hline Mean farm experience in years & 11 & \\
\hline \multicolumn{3}{|l|}{ Education } \\
\hline Formal education & 27 & 33.8 \\
\hline Primary education & 17 & 21.3 \\
\hline Secondary education & 32 & 40 \\
\hline Tertiary education & 4 & 5.0 \\
\hline $\begin{array}{l}\text { Mean number of years spent } \\
\text { schooling }\end{array}$ & 6 & \\
\hline \multicolumn{3}{|l|}{ Cropping pattern } \\
\hline Sole cropping & 36 & 45 \\
\hline Mixed cropping & 44 & 55 \\
\hline \multicolumn{3}{|l|}{ Land ownership } \\
\hline Owned farm land & 52 & 65 \\
\hline Rented & 28 & 35 \\
\hline \multicolumn{3}{|l|}{ Farm size in hectares } \\
\hline$<1$ & 45 & 47.5 \\
\hline$>1$ & 35 & 52.5 \\
\hline Mean farm size in hectares & 0.84 & \\
\hline Total & 80 & 100 \\
\hline
\end{tabular}

Source: Field data, 2019

\section{Technical Efficiency of the Yam Farmers}

Table 2 presents the maximum likelihood estimate of the technical efficiency and inefficiency of the sampled yam producers in the study area. The gamma $\gamma$ value which is associated with the variance of technical inefficiency effects in the stochastic frontier was estimated 0.99 and significant at $1 \%$. This suggests that systematic influences that are unexplained by the production function were the dominant sources of random errors. In other words, it means that $99 \%$ of the total variability of farm output was due to differences in technical efficiencies.

From the results, it is observed that all the explanatory variables except yam seedlings and fertilizer had the expected positive sign. This suggests that greater output of yam will be obtained by increasing quantities of these variables ceteris paribus. The estimated coefficient of land resource was positive and statistically significant at $1 \%$ level. This supports Umoh (2006) finding on resource use efficiency study in urban farming. The significance of the variable could be attributed to its importance in crop production in the sense that its shortage would not only have negative influence on production but would also exhibit indirect negative effect on output by reducing the marginal productivity of other resources used in yam production. The farm recorded Return to Scale (RTS) of 0.80 . This signifies existence of decreasing returns to the factors of production used by the farmers. This also implies that yam farmers were at Stage II region of production. Increasing the resource use would result in increase in yield ceteris paribus.

Yam seedling variable showed negative sign and was significant at $1 \%$ level. Implication of the negative sign means increase in the use of yam seedling for planting would result in low yield. This could likely be true because increasing plant population without the use of the requisite inputs like fertilizer, pesticides and adequate labour for weed control would result to poor yield instead of increase in the output. However, the result contradicts the finding of Orewa and Izekor (2012), which observed that the coefficients of farm size, yam seedlings, fertilizer and labour were positive and statistically significant. This suggested that more output of yam would be obtained from the use of additional quantities of these variables, ceteris paribus.

\section{Determinants of technical inefficiency}

The inefficiency variables were specified as those relating to farmers' socio-economic characteristics. Inefficiency result is interpreted differently. This is because a positive sign of an estimated parameter implies that the associated variable would exert a negative influence on technical efficiency and a negative sign indicates the variable would show positive influence on the technical efficiency. The variable, household size was negative but was significant at $5 \%$ level. The negative sign of the household coefficient implied that as the number of adult persons in a household increases, technical inefficiency would decrease, thereby increasing technical efficiency. This is so because members of same household will be diligent in carrying out farm activities since, they all share from the benefit of farming in terms of food consumption needs and income generation. This is in agreement with the hypothesized expected sign and supported the report of Itam et.al. (2015), which showed positive sign depicting that an increase in family size of cassava farmers in Cross Rivers State increased the average farm technical efficiency level in Nigeria. However, the finding is contrary to the report of Besseah, and Sangho, K (2014), which showed that household size showed a significantly negative impact on technical efficiency, which explained that technical efficiency of cocoa farms in Ghana reduced with increase in family size. A possible explanation is that, more adult persons in a household implied that more farm hands would be available in carrying out farming activities, thus making the production process more efficient. 
Table 2: Maximum likelihood estimates of technical efficiency and inefficiency

\begin{tabular}{llrrr}
\hline Efficiency Variables & Parameter & Coefficient & Standard error & t-value \\
\hline Constant & $\beta_{0}$ & 6.124 & 0.426 & $14.376^{* * *}$ \\
Farm size & $\beta_{1}$ & 1.431 & 0.143 & $10.022^{* * *}$ \\
Labour in man-days & $\beta_{2}$ & 0.036 & 0.042 & 0.874 \\
Yam seedling (kg) & $\beta_{3}$ & -0.553 & 0.164 & $-3.373^{* * *}$ \\
Fertilizer (kg) & $\beta_{4}$ & -0.123 & 0.097 & -1.263 \\
Inefficiency variables & & & & \\
Constant & $\delta_{0}$ & 3.140 & 1.328 & $-2.365^{* *}$ \\
Age & $\delta_{1}$ & 0.049 & 0.022 & $2.186^{* *}$ \\
Household size & $\delta_{2}$ & -0.113 & 0.052 & $-2.191^{* *}$ \\
Educational level & $\delta_{3}$ & .038 & 00.016 & $2.424^{* *}$ \\
Farming experience & $\delta_{4}$ & -0.002 & 0.022 & -0.108 \\
Diagnostic statistics & & & & \\
Sigma-squared & $\sigma^{2}$ & 0.010 & 0.027 & $3.502^{* * *}$ \\
Gamma & $\Gamma$ & 0.910 & 0.003 & $356.37^{* * *}$ \\
RTS (Return to Scale) & & 0.80 & & \\
Log likelihood function & & 126.954 & & \\
LR test of the one-sided error & 125.406 & & \\
\hline Note: & & &
\end{tabular}

Note: ${ }^{* * *}$ significant at $1 \%,{ }^{* *}$ significant at $5 \%,{ }^{*}$ significant at $10 \%$

Source: Field data, 2019.

The coefficient of educational level was positive and statistically significant at 5\% level. The positive sign implies that if an individual acquires more educational training, it would likely result to paying less attention to farm businesses. This could mainly due to the fact that acquiring higher educational status could increase an individual's opportunity of getting better alternative means of livelihood that will generate more and steady income for the household. Paying less attention to farm business would result in making wrong production management decisions which would increase technical inefficiency thereby decreasing the technical efficiency. The result is in contrast with the findings of Houngue and Nonvide (2020); Orewa and Izekor (2012) who observed that farmers level of education was negative and significantly related to technical inefficiency, which implied that farmers with more years of education were more technically efficient in farm production.

The result also indicated that the age coefficient was positive and statistically significant at 5\% level. This implies that as farmers increase in age, they would likely become less efficient in the management of the farm business. This is likely true because when farmers begin to age, they find it difficult to carry out strenuous farm tasks since farm operations require physical strength. This agrees with the finding of Dessie et al. (2020), which showed that age of producers, was statistically significant and positively influenced technical inefficiency of black cumin production in farming in northwest Ethiopia at 5\% of level of significance. However, Houngue and Nonvide (2020) observed that the variable age had a negative and significant coefficient on technical efficiency of farms in Benin. This according to the report implied that the younger producers allocate their resources more efficiently than the older ones. However, the coefficient of farming experience was not statistically significant; this is not difference from the findings of Hussain et al. (2012), who found that years of farming experience did not show any significant influence on technical inefficiency.
Table 3: Frequency distribution of technical efficiency of yam farmers in the study area

\begin{tabular}{lrr}
\hline Efficiency Range & Frequency & Percent \\
\hline $41-60$ & 2 & 2.5 \\
$61-80$ & 1 & 1.25 \\
$81-100$ & 77 & 96.25 \\
Mean & 94.6 & \\
Total & 80 & 100
\end{tabular}

Source: Field data, 2019

From the result in Table 3, it could be deduced that yam farmers were efficient in the use of inputs. An average farmer recorded technical efficiency of $94.6 \%$ which showed that they needed to increase resource us by about $5.4 \%$ to achieve the best possible frontier output of $100 \%$. The result suggests that farmers could increase farm yield if they make intensive use of land, labour, seed yam and fertilizer inputs. This disagree with Hussain et al. (2012) which found that a mean technical efficiency of the sampled farmers was 47.1 percent in Punjab, Pakistan, implying that on an average 52.9 percent of their technical potentials in wheat production are not being realized. The result disagrees with the findings of Ojo et al. (2009) and Shehu et al. (2010) which observed an efficiency gaps in the yam farms in Nigeria. Also on average, it is observed that $96.25 \%$ of the respondents operated in the efficiency range of 81-100 percent. This could be attributed to large family size available to perform farm operations timely. The study further showed that $3.75 \%$ of respondents achieved technical efficiency range of $81-100$ percent. This could be attributed to inadequate sensitization of farmers in the study area on the need to adopt new technology that would improve their farm outputs.

\section{Constraints}

Result in Table 4 showed that pest and diseases infestation was a militating factor to yam production. This could be due to poor access to farm inputs like pesticides and herbicides as indicated by the farmers. 
Table 4: Constraints faced by the yam farmers in the study area

\begin{tabular}{|c|c|c|c|c|c|c|}
\hline Perceived constraints & SA & $\mathrm{A}$ & $\mathrm{D}$ & SD & $\begin{array}{l}\text { Mean } \\
\text { score }\end{array}$ & Remarks \\
\hline High occurrence of pests and diseases & $\begin{array}{r}50 \\
(62.5)\end{array}$ & $\begin{array}{r}25 \\
(31.25)\end{array}$ & $\begin{array}{r}5 \\
(6.25)\end{array}$ & - & 3.575 & Serious problem \\
\hline Difficulty of access to improved variety & $\begin{array}{r}45 \\
(56.25)\end{array}$ & $\begin{array}{r}25 \\
(31.25)\end{array}$ & $\begin{array}{r}10 \\
(12.5)\end{array}$ & - & 3.485 & Serious problem \\
\hline $\begin{array}{l}\text { High cost of planting materials and farming } \\
\text { equipment }\end{array}$ & $\begin{array}{r}40 \\
(50)\end{array}$ & $\begin{array}{r}30 \\
(37.5)\end{array}$ & $\begin{array}{r}10 \\
(12.5)\end{array}$ & - & 3.375 & Serious problem \\
\hline High cost of farm labour & $\begin{array}{r}38 \\
(47.5)\end{array}$ & $\begin{array}{r}22 \\
(27.5)\end{array}$ & $\begin{array}{r}20 \\
(25)\end{array}$ & - & 3.225 & Serious problem \\
\hline High cost of land for yam production & $\begin{array}{r}20 \\
(25)\end{array}$ & $\begin{array}{r}16 \\
(20)\end{array}$ & $\begin{array}{r}14 \\
(17.5)\end{array}$ & $\begin{array}{r}30 \\
(37.5)\end{array}$ & 2.325 & $\begin{array}{l}\text { Not serious } \\
\text { problem }\end{array}$ \\
\hline Shortage of farm labour & $\begin{array}{r}25 \\
(31.25)\end{array}$ & $\begin{array}{r}15 \\
(18.75)\end{array}$ & $\begin{array}{r}18 \\
(22.5)\end{array}$ & $\begin{array}{r}22 \\
(27.5)\end{array}$ & 2.537 & Serious problem \\
\hline Inadequate capital for yam production & $\begin{array}{r}15 \\
(18.75)\end{array}$ & $\begin{array}{r}15 \\
(18.75)\end{array}$ & $\begin{array}{r}15 \\
(18.75)\end{array}$ & $\begin{array}{r}25 \\
(31.25)\end{array}$ & 2.125 & $\begin{array}{l}\text { Not serious } \\
\text { problem }\end{array}$ \\
\hline Difficulty of access to yam market & $\begin{array}{r}20 \\
(25)\end{array}$ & $\begin{array}{r}10 \\
(12.5)\end{array}$ & $\begin{array}{r}40 \\
(50)\end{array}$ & $\begin{array}{r}10 \\
(12.5)\end{array}$ & 2.500 & Serious problem \\
\hline
\end{tabular}

Source: Field Data, 2019

Note: $\geq 2.5=$ serious problem, $\leq 2.5=$ not serious problem.

It was also observed that difficulty in accessing improved yam variety was also a serious problem. This was mainly due to inadequate means of transportation or high cost of transportation. The result supports the finding of Ayanwuyi., Akinboye and Oyetoro (2011), which identified low soil fertility, lack of improved yam varieties, inadequate information on improved yam production practices, disease and pest attacks, high cost of higher labour among others as militating factors against yam production. In a similar study Ndubueze-Ogaraku and Ogbonna (2016) observed that $90.3 \%$ of farmers experienced insufficient fund, lack of credit facilities from the banks, pest and diseases among others were limiting factors to farming. Inadequate availability of capital required for the production of yam was not seen as a serious problem. However, shortage of farm labour required in carrying out farm operations is listed as a serious problem; this scenario is no doubt contributing to the scarcity of farm labour in the area. Labour scarcity in most rural communities is worsened by a new trend generating additional income, where a lot of young people are engaged in off farm jobs like okada riders (motor cycle transportation business) and mini car town shuttles.

\section{CONCLUSIONS AND RECOMMENDATIONS}

The study estimated the determinants of technical efficiency and inefficiency levels among small-holders' yam farms in Nigeria. The study concludes that male farmers dominated in yam production business in the study area. Mean technical efficiency of farmers was $94.6 \%$. The variable farm size increased technical efficiency level while yam seedlings significantly reduced technical efficiency. Age variable showed negative effects on technical efficiency while number of persons per household increased technical efficiency level. High occurrence of pests and diseases, high cost of farm inputs (planting materials and farming equipment), high cost and shortage of farm labour among others, were major challenges faced by farmers while high cost of land for yam production and inadequate capital for yam production were the minor challenges. Government should review and strengthen its policy on the provision of incentives such as access to affordable inputs, including loan, subsidies and grants. Finally, more awareness should be created to encourage young people to participate in farm business, especially yam production, since older farmers are becoming less efficient in the management of their farms. Inadequate funds and insecurity challenges in Nigeria limited the study locations to Ekiti State, Nigeria. Further research should be expanded to cover all agricultural zones in Nigeria, this would help identify regions where yam farmers are farm technical efficiency level in different regions and identify factors that would improve resource use efficiency in among yam producers.

\section{Acknowledgement}

The authors wish to thank small-scale yam producers in the Ekiti State, Nigeria for providing us with useful information concerning their farm businesses for this study. Also, many thanks to the Department of Agricultural Economics and Extension, University of Port Harcourt for providing conducive environment and facilities used during the study.

\section{REFERENCES}

AJIBEFUN, I. A., \& ABDULKADRI, A. O. (1999). An investigation of Technical inefficiency of production of farmers under the National Directorate of Employment in Ondo State, Nigeria. APP Economics Letter. $\quad(6)$ : 111-114. https://doi.org/10.1080/135048599353735

AHMED, M. A., MOHAMED, Z. A., NAWI, N. M., \& ILLIYASU, A. (2016). Technical efficiency analysis of smallholder maize farmers in north eastern Nigeria. British Journal of Economics, Finance and Management Sciences 12(2): $24 \quad-33$. 
http://www.ajournal.co.uk/EFpdfs/EFvolume12( 2)/EFVol.12\%20(2)\%20Article\%203.pdf

AIGNER, D., LOVELL, C. A. K., \& SCHMIDT, P. (1977). Formulation and estimation of stochastic frontier production function models. Journal of Econometrics. (6): 21-37. https://doi.org/10.1016/0304-4076(77)90052-5

AKANDE, S. O., \& OGUNDELE, O. O. (2009). Yam production in Nigeria. A policy analysis matrix, In: NKAMLEU, B. ANNANG, D., \& BACCO, N. M. (Eds.). Securing livelihoods through yams Nigeria. IITA. Pp $10-25$.

AYANWUYI, E., AKINBOYE, A. O., \& OYETORO, J. O. (2011). Yam production in Orire local government area of Oyo State, Nigeria: Farmers perceived constraints. World Journal of Young Researchers. $1(2)$ : 16-19. https://www.academia.edu/3131068/Yam_Production in_Orire Local

AZUMAH, S. B, DONKOH, S. A., \& AWUNI, J. A. (2019). Correcting for sample selection in stochastic frontier analysis: insights from rice farmers in Northern Ghana. Agricultural and Food Economics. 7(9), p. 1-15. https://doi.org/10.1186/s40100-0190130-Z

BABALEYE, T. (2005). Improving yam production technology West Africa, ANB- BI supplement Issue/Edition Nr 463.

BAMIRE A. S., \& AMUJOYEBE, B. J. (2005). Economic analysis of land improvement techniques in small holder. yam-based production systems in the agroecological zones of South Western, Nigeria. J. Human Ecol. $18(1), \quad$ p. $1-12$. https://doi.org/10.1080/09709274.2005.11905799

BATTESE, G. E., \& COELLI, T. J. (1995). A model for technical inefficiency effects in stochastic frontier production function for panel data. Empirical Economics. 20, 325-335. https://doi.org/10.1007/BF01205442

BESSEAH, F. A., \& SANGHO, K. (2014). Technical efficiency of cocoa farmers in Ghana. Journal of Rural Development/Nongchon-Gyeongje, 37(2), 159-182, 10.22004/ag.econ.196615

DESSIE, A. B., ABATE, T. M., ADANE, B. T., TESFA, T., \& GETU, S. (2020). Estimation of technical efficiency of black cumin (Nigella sativa L.) farming in northwest Ethiopia: a stochastic frontier approach. Journal of Economic Structures. (9)18, 1-14. https://doi.org/10.1186/s40008-020-00198-1

EDEH, H. O., \& AWOKE, M. U. (2009). Technical efficiency analysis of improved cassava farmers in Abakaliki Local Government Area of Ebonyi State: A stochastic frontier approach. Agricultural Journal, 4(4), p.

171-174. https://medwelljournals.com/abstract/?doi=aj.2009.17 1.174

EKUNWE, P. A., OREWA, S. I., \& EMOKARO, C. O. (2008). Resource use efficiency in yam production in Delta and Kogi States of Nigeria. Asian Journal of Agricultural Research, 2(2): 61-69. $\underline{10.3923 / a j a r .2008 .61 .69}$
FAO. Food and Agriculture Organization (FAO) (2008). Food and nutrition, creating a well fed world, FAO, Rome, Italy. Food and Agriculture Organization Year Book. 56: 13 - 18.

HOUNGUE, V., \& NONVIDE, G. M. A. (2020). Estimation and determinants of efficiency among rice farmers in Benin, Cogent Food \& Agriculture, 6(1), 123. https://doi.org/10.1080/23311932.2020.1819004

HUSSAIN, A., SABOOR, A., KHAN, M. A., MOHSIN, A. Q., \& HASSAN, F. ul. (2012). Technical efficiency of wheat production in rain-fed areas: A case study of Punjab, Pakistan. Pak. J. Agri. Sci. 49(3), 411-417; 2012

IITA. International Institute of Tropical Agriculture (2007). Root and tuber system: yam. International Institute for Tropical Agriculture, Ibadan. The Annual report IITA

IITA. International Institute of Tropical Agriculture (2008). Research highlight on plant density of yam minisett, International Institution of Tropical Agriculture. The Annual report IITA 114-118.

ITAM, K. O., AJAH, E. A., OFEM, U, I., \& ABAM, O. E. (2015). Technical efficiency analysis of small scale cassava farmers in Cross Rivers State, Nigeria: A stochastic production frontier approach. Applied Economics \& Finance. 2(4), 10-18, https://doi.org/10.11114/aef.v2i4.1028

IZEKOR, O. B., \& OLUMESE, M. I. (2010). Determinants of yam production and profitability in Edo State, Nigeria. Afr. J. General. Agric. 6(4): 30-35.

NDUBUEZE-OGARAKU, M. E., \& OGBONNA, M. C. (2016). Analysis of technical efficiency and its determinants in rice production: Evidence from Abia State. Nigerian Agricultural Policy Research Journal. 1 (1), p. 38-50. 10.22004/ag.econ.292057

NBS. National Bureau of Statistics of the Federal Republic of Nigeria (2017). Nigeria agricultural production: Yam 1995-2015. NBS, Abuja. https://www.ceicdata.com/en/nigeria/agriculturalproduction

NBS. NATIONAL BUREAU OF STATISTICS. (2012). LSMS-Integrated surveys on agriculture: General household survey panel 2010/11.

NPC. National Population Commission (2006). Legal notice on publication of 2006 census final results. Federal Republic of Nigeria Official Gazette, Abuja 2 (96), 1- 42

MANGO, N., MAKATE., C. HANYANI-MLAMBO, B., SIZIBA, S., \& LUNDY, M. (2015). A stochastic frontier analysis of technical efficiency in smallholder maize production in Zimbabwe: The post-fast-track land reform outlook. Cogent Economics and Finance, 3(1), p. 1-14. https://doi.org/10.1080/23322039.2015.1117189

MUHAMMAD-LAWAL, A., OMOTESHO, O. A, \& FALOLA, A. (2009). Technical efficiency of youth participation in agriculture: A Case study of the youth - in - agriculture programme in Ondo State, South Western Nigeria. Nigerian Journal of Agriculture, Food and Environment 5(1): 20-26

OJO, M. A., MOHAMMED, U. S., OJO, A. O., \& OLALEYE, R. S. (2009). Return to scale and 
determinants of farm level technical inefficiency among small scale yam based farmers in Niger State, Nigeria: Implication for food security. International Journal of Agricultural Economics and Rural Development. 2 (1): 43 - 51.

OKORUWA, V. O., OGUNDELE, O. O., \& OYEWUSI, B. O. (2006). Efficiency and productivity of farmers in Nigeria: a study of rice farmers in North Central Nigeria. Poster paper prepared for presentation at the International Association of Agricultural Economists Conference, Gold Coast, Australia, August, 12-18 2006

OLADEEBO, J. O., \& OKANLAWON, O. (2010). Profitability level of yam (Dioscorea spp) production in Oyo State. In Akinlade, J. A., Ogunwole, A. B., Asaolu, V. O., Ademola, O. A., Oyebiyi, O. O., Rafiu, T. A., Olayeni, T. B. \& Yekinni O T (eds) Proceedings of the 44th Annual Conference of the Agricultural Society of Nigeria, LAUTECH, Ogbomoso 18th -22nd October, 2010.

OLUWATUSIN, F. M. (2011). Measuring technical efficiency of yam farmers in Nigeria: A stochastic parametric approach. Agricultural Journal. 6 (2), p. 40-46.

ONYENWEAKU, C. E., IGWE, K. C. \& MBANASOR, J. A. (2005). Application of a stochastic frontier production function to the measurement of technical efficiency in yam production in Nasarawa, State, Nigeria Journal of Sustainable Tropical Agriculture Research, 13: 20-25.
ONWUEME, I. C. (2008). The tropical tuber crops-yams, cassava, sweet potato and cocoyams. John Wiley and Sons. Chichester.UK pp 3-101.

OREWA, S. I., \& IZEKOR, O. B. (2012). Technical efficiency analysis of yam production in Edo State: A stochastic frontier approach. International Journal of Development and Sustainability. 1 (2): 516-526

REUBEN, J., \& BARAU, A. D. (2012). Resource use efficiency in yam production in Taraba State, Nigeria. Journal of Agricultural Sciences, 3(2), p. 71-77. https://doi.org/10.1080/09766898.2012.11884687

SHEHU, J. F., IYORLYER, J. T., MSHELIA, S. I., \& JONGUR, A. A. (2010). Determinant of yam production and technical efficiency among yam farmers in Benue State, Nigeria. Journal of Social Science. 24(2), p.143-148. https://doi.org/10.1080/09718923.2010.11892846

UMOH G. S. (2006). Resource use efficiency in urban farming: an application of stochastic frontier production function. International Journal of Agriculture \& Biology. 8(1), p. 38 - 44.

ZAKNAYIBA, D. B., \& TANKO, L. (2013). Costs and returns analysis of yam production among small scale farmers in Karu LGA, Nasarawa State, Nigeria. Production Agriculture and Technology Journal (PATJ) 9(1): 73-80. 